\title{
DZIALANIA PROMOCYJNE KOŚCIELNYCH BIBLIOTEK NAUKOWYCH NA PRZYKLADZIE BIBLIOTEKI TEOLOGICZNEJ UNIWERSYTETU ŚLĄSKIEGO W KATOWICACH
}

\section{Wprowadzenie}

Wielu autorów piszących o zarządzaniu oraz kulturze organizacyjnej podkreśla, że współczesna biblioteka musi wyraźnie zaistnieć w świadomości społecznej, aby liczyć na wsparcie otoczenia ${ }^{1}$. Ponadto ciągle musi przypominać o swoim istnieniu i działalności, dbać o kształtowanie pozytywnego wizerunku, podejmując różnego rodzaju działania marketingowe i promocyjne ${ }^{2}$. Wprawdzie nie brak jeszcze w środowisku przeświadczenia, że biblioteka, a szczególnie biblioteka kościelna nie powinna namawiać do korzystania z usług, ponieważ jej społeczna użyteczność jest oczywista. To jednak właśnie jej specyfika polegająca na realizacji funkcji naukowo-dydaktycznej i dodatkowo ewangelizacyjnej ${ }^{3}$, wymaga ustawicznego przypominania o swojej ważności i użyteczności. To dzięki zastosowaniu nowoczesnych instrumentów promocyjnych, takich jak reklama, public relations (dalej: PR), promocja osobista lub uzupełniająca, zyskuje ona możliwość stworzenia sprawnie funkcjonującego systemu komunikowania się z otoczeniem ${ }^{4}$.

* Agata Muc - mgr bibliotekoznawstwa i informacji naukowej, adiunkt biblioteczny w Bibliotece Teologicznej Uniwersytetu Śląskiego.

${ }^{1}$ M.in. J. Wojciechowski, Organizacja i zarzadzanie w bibliotekach, Warszawa 1998, ss. 283; M. Wojciechowska, Zarzadzanie zmianami w bibliotece, Warszawa 2006, ss. 301.; Zarzadzanie marketingowe biblioteka, red M. Pigla i in., Poznań 2008, ss. 220; Zarzadzanie strategiczne i marketingowe w bibliotekach, red. M. Nowak i in., Poznań 2004, ss. 169; E. B. Zybert: Kultura organizacyjna w bibliotekach, Warszawa 2004, ss. 247.

${ }^{2}$ Zob. Marketing biblioteczny, red. M. Wojciechowska, Gdańsk 2007, ss. 192; Marketing i jakość uslug bibliotek akademickich, red. S. Kubów, Wrocław 2002, ss. 146; Marketing wyzwaniem dla wspótczesnej biblioteki, red. D. Marzec, P. Marzec, Lublin 2006, ss. 70; J. Wojciechowski, Marketing w bibliotece, Warszawa 1993, ss. 183.

${ }^{3}$ J. Biernacki, Biblioteki kościelne w stużbie ewangelizacji, „Archiwa, Biblioteki i Muzea Kościelne" [dalej: ABMK], 91 (2009) s. 5.

${ }^{4}$ Zob. Public relations, red. M. Kocójowa, Kraków 2004, ss. 359. 
W tym miejscu warto przypomnieć pojęcie promocji bibliotecznej definiowanej przez Jana Sójkę jako „zespół działań i środków za pomocą, których biblioteka przekazuje otoczeniu informacje charakteryzujące ją lub jej zbiory i usługi, kształtuje potrzeby użytkowników oraz pobudza i ukierunkowuje popyt"s. Przede wszystkim pełni więc funkcję informacyjną w systemie komunikowania się biblioteki z otoczeniem i służy akceptacji środowiska dla realizowanych przez bibliotekę funkcji. Poza tym wpływa na zmniejszenie dystansu między ofertą biblioteczną a czytelnikiem, co sprzyja tworzeniu pozytywnego wyobrażenia o instytucji6.

Biblioteka Teologiczna (dalej: BT) od początku swojej działalności, tj. od momentu przekształcenia Biblioteki Wyższego Śląskiego Seminarium Duchownego w bibliotekę Wydziału Teologicznego Uniwersytetu Śląskiego (dalej: WT UŚ) utworzonego w 2001 roku, stara się systematycznie promować zarówno swoje zbiory, jak i usługi. Ze względów organizacyjnych oraz kadrowych (w bibliotece zatrudnionych jest siedem osób) nie powołano specjalnego działu ani nie wyznaczono konkretnej osoby, która byłaby odpowiedzialna za tego rodzaju działania. Jednak każdego dnia pracy cały personel stara się uczestniczyć w tworzeniu pozytywnego wizerunku instytucji wykorzystując te instrumenty i możliwości, które nie pociągają za sobą (większych) kosztów i nie zakłócają jej funkcjonowania. W artykule przedstawiono cztery aspekty działalności bibliotecznej - działalność wystawienniczą i wydawniczą, kontakty z otoczeniem i dydaktykę, które bezpośrednio lub pośrednio służą promowaniu instytucji w dłuższym okresie czasu.

\section{Działalność wystawiennicza reklamą zasobów bibliotecznych}

Reklama wystawiennicza jest jedną z najczęściej wykorzystywanych form promocji bibliotecznej, o czym świadczą liczne przykłady prezentowane w literaturze fachowej ${ }^{\top}$. Stosunkowo niewielkim nakładem środków finansowych, wykorzystując własne materiały oraz umiejętności i wiedzę personelu, można zareklamować nie tylko księgozbiór i oferowane usługi, ale także samą bibliotekę. Ponadto nowoczesne technologie pozwalają obecnie na wyjście z ekspozycjami poza mury książnicy i umieszczanie ich w Internecie, co w znacznym stopniu poszerza grono odbiorców i pozwala nawet małym placówkom zaistnieć także poza lokalną społecznością, często ograniczoną do macierzystej uczelni ${ }^{8}$. Prowadzenie dzia-

${ }^{5}$ J. Sójka, Promocja w strategii marketingowej biblioteki, Poznań 1994, s. 62.

${ }^{6}$ A. Szulirz-Ficek, Promocja $w$ działalności biblioteki pedagogicznej, w: Zarzadzanie marketingiem $w$ organizacjach niedochodowych, red. A. Chodyński, M. Huczek, I. Socha, Sosnowiec 2002 , s. 166.

${ }^{7}$ Zob. np. E. Budkiewicz, R. Mroczek, Marketingowa rola wystaw, „Bibliotekarz”, 11 (1995) s. 15-18; W. Michna, O wystawach w bibliotece, „Poradnik Bibliotekarza”, 2 (1994) s. 28-30; B. Mikuszewska-Kamińska, R. Mroczek, Percepcja form ekspozycji organizowanych przez biblioteke naukowa, „Bibliotekarz”, 4 (1999) s. 20-23; M. Zmitrowicz, Wystawy w Bibliotece Głównej Uniwersytetu Kazimierza Wielkiego w Bydgoszczy, „Bibliotekarz”, 6 (2008) s. 23.

${ }^{8}$ D. Murzynowska, J. Potęga, Nie tylko biblioteka cyfrowa ... - rzecz o bibliotecznych wystawach wirtualnych [dokument elektroniczny], „Biuletyn EBIB”, 11 (2006). Tryb dostępu: http:// www.ebib.info/2006/81/murzynowska_potega.php. [Data dostępu: 8.11.2011]. 
łalności wystawienniczej w bibliotece ma przede wszystkim znaczenie dla realizacji funkcji informacyjnych, propagandowych oraz $\mathrm{kształcących}^{9}$, ale nie wolno zapominać także o tym, że dodatkowo stwarza szansę włączenia się w upowszechnianie i dokumentowanie kultury. Nowoczesna biblioteka akademicka jako instytucja publiczna i otwarta ma do spełnienia ważną rolę w życiu uczelni, oprócz ściśle naukowej i dydaktycznej, coraz częściej przypisuje się jej również rolę kulturotwórczą ${ }^{10}$. Jest to szczególnie ważny aspekt działalności także bibliotek kościelnych, co podkreśla Papieska Komisja ds. Dóbr Kulturowych Kościoła w liście z 1994 roku, skierowanym do arcybiskupów, biskupów i przełożonych generalnych zgromadzeń zakonnych, nazywając je wręcz „laboratoriami kulturowymi”" . Wiele spośród księgozbiorów kościelnych jest niezwykle bogatych i wartościowych, często są odzwierciedleniem wielowiekowej historii Kościoła oraz stanowią intelektualny dorobek ludzkości, dlatego tak ważna jest ich rola w dążeniu zarówno do zachowania, jak i tworzenia kultury ${ }^{12}$.

Rozumiejąc tak złożoną rolę i powinność kościelnej biblioteki uczelnianej, pracownicy BT starają się promować swoją książnicę jako miejsce upowszechniania nauki, kultury i sztuki, wykorzystując w tym celu planową i systematyczną działalność wystawienniczą. Organizują zarówno stałe ekspozycje nowości wydawniczych, jak i okresowe wystawy tematyczne i okolicznościowe. Podczas dziesięcioletniej historii instytucji zorganizowano ponad siedemdziesiąt wystaw tematycznych, a bogaty i jednocześnie interdyscyplinarny księgozbiór pozwala na ciągłą zmianę eksponatów, co sprawia że czytelnicy mają możliwość zapoznania się z często unikatowymi zasobami książnicy. W gablotach obok książek oraz czasopism prezentowane bywają różnego rodzaju dokumenty życia społecznego, jak fotografie, plakaty, dyplomy, rękopisy, foldery, zaproszenia, ulotki itp. Początkowo wystawy były usytuowane w budynku Wyższego Śląskiego Seminarium Duchownego w części przeznaczonej dla BT oraz WT, co bezpośrednio wpływało na wielkość i liczebność ekspozycji. Sytuacja uległa zmianie w 2007 roku, kiedy to oprócz gablot umieszczonych w bezpośrednim sąsiedztwie wypożyczalni oraz czytelni, biblioteka dostała możliwość zagospodarowania wydzielonej powierzchni w holu nowo wybudowanego i przestronnego gmachu WT. Od tego momentu daje się zauważyć wyraźny wzrost aktywności na tym polu, zwiększyła się zasobność i częstotliwość przygotowywanych ekspozycji.

Wiodącym nurtem w dotychczasowej działalności wystawienniczej książnicy było prezentowanie osiągnięć macierzystego WT oraz zatrudnionych w nim pracowników naukowyo-dydaktycznych. Jedną z najlepszych okazji do promowania wydziału, a przy tym także zasobów jego biblioteki, było tworzenie wystaw jubileuszowych z okazji obchodów dziesiątej rocznicy powołania samego wydziału

${ }^{9}$ Encyklopedia wiedzy o książce, Warszawa 1971, s. 2556-2557.

${ }^{10}$ A. Chachlikowska, Kulturotwórcza rola biblioteki naukowej na przykładzie Biblioteki Uniwersyteckiej w Poznaniu, w: Biblioteki naukowe w kulturze i cywilizacji w kulturze i cywilizacji: działania i codzienność, t. 1, red. H. Ganińska, Poznań 2005, s. 135.

${ }^{11}$ F. Marchchisano, Biblioteki kościelne w misji Kościoła, „FIDES: Biuletyn Bibliotek Kościelnych" [dalej: FIDES], 1-2 (1996) s. 37.

${ }_{12}$ J. Bednarczyk, Zasoby bibliotek kościelnych $w$ tworzeniu i zachowaniu kultury, ABMK, 86 (2006) s. 55-63. 
oraz czterdziestolecia UŚ. Prezentowano wówczas historię i organizację uczelni i biblioteki, bogaty dorobek kadry naukowej oraz osiągnięcia studentów skupionych wokół Studenckiego Koła Naukowego Teologów. Z kolei jubileusz czterdziestolecia pracy naukowej pierwszego dziekana WT ks. prof. dr. hab. Wincentego Myszora był okazją do przygotowania wystawy zatytułowanej „Omnia Tempus Hebant - Wszystko ma swój czas". Bibliotekarze zaprezentowali wówczas księgę jubileuszową ${ }^{13}$ dedykowaną jubilatowi oraz bogatą kolekcję publikacji jego autorstwa. Planowane bywają także wystawy okolicznościowe odnoszące się do ważnych wydarzeń mających miejsce na terenie WT, jak chociażby uroczystości nadania tytułu doktora honoris causa UŚ. Dotychczas tytuł taki otrzymali dwaj wybitni przedstawiciele polskiego Kościoła katolickiego - Wielki Kanclerz WT, ks. arcybiskup Damian Zimoń oraz prefekt Watykańskiej Kongregacji Edukacji Katolickiej, ks. kardynał Zenon Grocholewski. Przybyli na uroczystości goście mogli obejrzeć w holu WT zbiory biblioteczne będące odzwierciedleniem nie tylko pracy naukowej obydwu księży, ale także dokumentację dokonań na polu duszpasterskim, społecznym i organizacyjnym.

$\mathrm{Na}$ wydziale odbywają się liczne konferencje, seminaria i sesje naukowe, do których bibliotekarze przygotowują również oprawę w postaci wystaw. Takim wydarzeniem była sesja naukowa poświęcona czterdziestoleciu Śląskich Studiów Historyczno-Teologicznych, jednemu z najstarszych naukowych czasopism diecezjalnych, która zgromadziła redaktorów, autorów oraz twórców periodyku. Biblioteka oprócz wyeksponowania kompletu numerów periodyku i prezentacji sylwetek wszystkich redaktorów naczelnych, wzbogaciła wystawę o źródłowe materiały archiwalne dotyczące początków i rozwoju czasopisma. Podobną oprawę w postaci plakatu, ulotek oraz wyboru literatury miała konferencja naukowa Teologia i polityka. Czy istnieje w Polsce teologia polityczna? Natomiast dopełnieniem warsztatów sinologicznych zorganizowanych przy okazji obchodów Dnia Modlitwy za Kościót w Chinach przez Zakład Misjologii i Teologii Religii WT, była wystawa zatytułowana „Zbiory sinologiczne Biblioteki Teologicznej”. Należy w tym miejscu podkreślić, że większość wystaw tematycznych została przygotowana po konsultacjach i w ścisłej współpracy z pracownikami naukowymi wydziału.

Biorąc pod uwagę specyfikę uczelni teologicznej i jednocześnie wychodząc naprzeciw oczekiwaniom użytkowników bibliotekarze starają się także wskazywać na publikacje odnoszących się do ważnych postaci czy momentów w życia Kościoła katolickiego. Dlatego nie dziwi fakt, że niektóre z ekspozycji poświęcono najważniejszym osobom dla współczesnego Kościoła, tj. błogosławionemu Janowi Pawłowi II oraz papieżowi Benedyktowi XVI ${ }^{14}$. Z kolei jubileusze kościelne stały się okazją do zaprezentowania sylwetek osób, które odegrały szczególną rolę w historii oraz tradycji chrześcijańskiej. I tak na czas obchodów Roku Świętego Pawła z okazji 2000-lecia narodzin, bibliotekarzom udało się przygoto-

${ }^{13}$ Zob. Omnia Tempus Hebant: Miscellanea theologica Vincentio Myszor quadragesimum annum laboris scientifici celebranti ab amicis, sodalibus discipulisque oblata, red. A. Reginek, G. Strzelczyk, A. Żądło, Katowice 2009, 593 s.

${ }^{14}$ B. Warząchowska, Ekspozycje zbiorów Biblioteki Teologicznej, FIDES, 1-2 (2007) s. 81-82. 
wać wystawę złożoną tylko z dysertacji jemu poświęconych, a powstałych w Wyższym Sląskim Seminarium Duchownym oraz WT. Natomiast Rok Kapłański ustanowiony przez papieża Benedykta XVI z okazji 150. rocznicy śmierci św. Jana Marii Vianney'a, znanego powszechnie jako Proboszcz z Ars, był okazją do przybliżenia jego dokonań za pośrednictwem polskich i obcojęzycznych zbiorów bibliotecznych. W podobny sposób uhonorowano ważne postaci dla Kościoła lokalnego, a byli nimi biskupi śląscy: August Hlond, Arkadiusz Lisiecki, Stanisław Adamski i Herbert Bednorz ${ }^{15}$.

Planując tematykę kolejnych ekspozycji bibliotekarze nie zapominają również o promowaniu zawartości własnego księgozbioru. Realizacji takiego celu służyły wystawy: Dokumenty elektroniczne w Bibliotece Teologicznej, CORPUS CHRISTIANORUM $i$ inne źródła do badań teologicznych oraz prezentacja wydzielonej części z bogatego daru ks. arcybiskupa Szczepana Wesołego. Kolejny istotny aspekt aktywności wystawienniczej to promowanie czytelnictwa, edytorstwa i ochrony własności intelektualnej za pomocą praw autorskich podczas obchodów „Światowego Dnia Książki”. Dla bibliotekarzy święto to stało się pretekstem do zaprezentowania współczesnemu pokoleniu różnorodnych form wydawniczych i piśmienniczych książek. Tym razem w gablotach znalazły się pozycje wybrane ze względu na bogatą lub oryginalną szatę graficzną. Zwiedzający mieli możliwość zapoznania się z historią książki oraz jej zmieniającą się na przestrzeni dziejów formą wydawniczą.

Głównymi pomysłodawcami i wykonawcami przeważającej części ekspozycji są pracownicy BT, jednak w dotychczasowej działalności wystawienniczej zdarzały się również wystawy, które przygotowywano we współpracy z innymi instytucjami. W wyniku współpracy z firmami zajmującymi się importem literatury zagranicznej - A.B.E. Marketing oraz International Publishing Service - doszło do zorganizowania prezentacji najnowszych obcojęzycznych publikacji naukowych. Wystawy były dużymi przedsięwzięciami organizacyjnymi, gdyż za każdym razem liczyły ponad tysiąc tytułów książek i przyciągnęły wielu oglądających oraz kupujących ${ }^{16}$. Z kolei wraz z Muzeum Archidiecezjalnym w Katowicach przygotowano ekspozycję zatytułowaną „Kościół na Górnym Śląsku a sztuka niezależna", która towarzyszyła sesji popularnonaukowej Kościót a kultura niezależna $w$ latach $80^{17}$. Było to znaczące wydarzenie o zasięgu ogólnopolskim i przyciągnęło wielu przedstawicieli nauki oraz sztuki. Spotkanie poprzedziła akcja reklamowa, a informacje na temat sesji i towarzyszącej mu wystawy prezentowano na plakatach, ulotkach i katalogach oraz w mediach.

${ }^{15}$ B. Warząchowska, Promocja zbiorów Biblioteki Teologicznej w Katowicach, FIDES, 1-2 (2010) s. 152.

${ }^{16} \mathrm{~B}$. Warząchowska, Wystawa naukowej książki zagranicznej w Bibliotece Teologicznej, „Gazeta Uniwersytecka UŚ”, 4 (2003) s. 9-10; B. Warząchowska, Wystawy, kiermasze, targi-książki do nas czy my do ksiażek, FIDES, 1-2 (2004) s. 86-89.

${ }^{17}$ A. Burda-Szostek, Artyści z Kościotem: sesja na Wydziale Teologicznym, „Gość Niedzielny” Dodatek Katowicki, 4 (2010) s. 3; E. Olszowy, Sprawozdanie z wystawy „Kościót na Górnym Ślasku a sztuka niezależna”, „Bibliotheca Nostra”, 1 (2010) s. 97-102; M. Sztuka, Katowicki underground: sesja popularnonaukowa „,Kościót a kultura niezależna w latach 80”, „Gazeta Uniwersytecka UŚ", 6 (2010) s. 18-19. 
Efekty promocyjne działalności wystawienniczej nie zawsze są widoczne od razu, nie przekłada się ona bowiem bezpośrednio na zwiększenie liczby wypożyczeń czy przychodzących czytelników, ale na pewno ułatwia dotarcie z informacją o zasobach i usługach bibliotecznych oraz w pośredni sposób wpływa za budowę pozytywnego wizerunku książnicy w środowisku.

\section{Publikacje bibliotekarzy jako element public relations}

Jedną z podstawowych funkcji PR jest stała i systematyczna komunikacja biblioteki z otoczeniem. Przy czym komunikacja taka powinna mieć na względzie przekazywanie obszernych informacji na temat funkcjonowania biblioteki w celu zapoznania się z ofertą, zachęcania do korzystania z jej usług oraz wykreowania pozytywnego wizerunku samej instytucji zarówno w otoczeniu bliższym, jak i dalszym ${ }^{18}$.

Podstawowym sposobem przekazywania informacji na temat działalności BT jest staranne redagowanie strony domowej biblioteki, w której na bieżąco są pokazywane wszystkie aspekty jej funkcjonowania, zbiory oraz pełny zakres oferowanych usług ${ }^{19}$. Strona internetowa to współczesny element autoprezentacji i oferty, będący wirtualną wizytówką biblioteki. Dzięki informacjom tam zamieszczonym czytelnik może zapoznać się z najważniejszymi usługami placówki oraz dowiedzieć się, jakie warunki musi spełnić, aby móc w pełni skorzystać z jej zasobów $^{20}$. Nie mniej ważnym środkiem wspomagającym PR jest aktywność wydawnicza kadry bibliotecznej. Bibliotekarze od dawna promują działalność swoich książnic zamieszczając informacje na ich temat w ogólnopolskiej prasie fachowej ${ }^{21}$ oraz innego rodzaju publikacjach kierowanych do środowiska bibliotekarskiego ${ }^{22}$. Obecnie wiele bibliotek uczelnianych wydaje własne czasopisma w formie drukowanej lub elektronicznej, w których oprócz sprawozdań czy omówień prezentowane są także wyniki prac naukowo-badawczych oraz bibliograficznych $^{23}$. Publikacje tego rodzaju przyczyniają się do budowania wizerunku biblio-

${ }^{18}$ M. Wojciechowska, Spoteczne komunikowanie sie biblioteki z otoczeniem. Istota, cele i zasady bibliotecznego PR, w: Przestrzeń informacyjna biblioteki akademickiej - tradycja i nowoczesność, red. B. Antczak-Sabla, M. Kowalska, L. Tkaczyk, Toruń 2009, s. 274.

${ }_{19}$ Zob. Strona internetowa Biblioteki Teologicznej Uniwersytetu Śląskiego. Tryb dostępu: http://bt.us.edu.pl/ [Data dostępu: 8.11.2011].

${ }^{20}$ Elektroniczny wizerunek biblioteki, red. M. Wojciechowska, Gdańsk 2008, s. 188; W. Jachym, Public relations w bibliotece uczelnianej Państwowej Wyższej Szkoły Zawodowej w Tarnowie. Możliwości, przykłady, propozycje działań, w: Przestrzeń informacyjna, s. 288.

${ }^{21}$ A. Iljasz, Promocja działalności bibliotek w prasie fachowej dla bibliotekarzy w PRL od 1956 r., w: Bibliologia polityczna, red. D. Kuźmina, Warszawa 2011, s. 387-397.

${ }^{22}$ M. Kycler, B. Warzachowska, Dorobek naukowo-badawczy bibliotekarzy Uniwersytetu Ślaskiego w Katowicach jako element komunikacji społecznej, „Nowa Biblioteka”, 2 (2010) s. 119-145 .

${ }^{23}$ Zob. np. Rocznik wydawany przez Bibliotekę Uniwersytecką w Poznaniu - „Biblioteka”; Rocznik wydawany przez Bibliotekę Główną i Zakład Nauk Pomocniczych Historii i Bibliotekoznawstwa Uniwersytetu Marii Curie-Skłodowskiej w Lublinie - „Folia Bibliologica: Biuletyn Biblioteki Głównej UMCS". 
teki postrzeganej jako jednostki aktywnej i nowoczesnej, mającej duże znaczenie dla społeczności akademickiej.

Podczas dziesięcioletniej historii książnicy zatrudnione w niej osoby opublikowały w sumie ponad osiemdziesiąt artykułów, recenzji oraz sprawozdań (niektóre znajdują się jeszcze $\mathrm{w}$ druku ${ }^{24}$. Przeważająca część z nich poświęcona została działalności BT oraz jej księgozbiorowi, a tylko nieliczne stanowiły wyniki badań będących rezultatem indywidualnych zainteresowań bibliotekarzy. Prace ukazywały się zarówno w prasie lokalnej, jak i ogólnopolskich czasopismach fachowych. Częstotliwość z jaką publikowano pokazuje poniższa tabela.

Tabela 1. Liczba publikacji pracowników BT zamieszczonych w czasopismach w la tach 2002-2010

\begin{tabular}{|c|c|c|c|c|c|c|c|c|c|}
\hline $\begin{array}{c}\text { Tytuly } \\
\text { czasopism }\end{array}$ & 2002 & 2003 & 2004 & 2005 & 2006 & 2007 & 2008 & 2009 & 2010 \\
\hline $\begin{array}{l}\text { Archiwa, } \\
\text { Biblioteki i Muzea } \\
\text { Kościelne } \\
\end{array}$ & & & 1 & & & 1 & 1 & & \\
\hline $\begin{array}{l}\text { Bibliotheca } \\
\text { Nostra }\end{array}$ & & & & & & 1 & & 3 & 4 \\
\hline Biuletyn EBIB & 2 & 1 & 1 & & & & & & \\
\hline $\begin{array}{l}\text { FIDES: } \\
\text { Biuletyn Bibliotek } \\
\text { Kościelnych } \\
\end{array}$ & & 1 & 3 & 2 & 4 & 2 & 2 & 5 & 6 \\
\hline $\begin{array}{l}\text { Gazeta Uniwersytec- } \\
\text { ka UŚ }\end{array}$ & 3 & 3 & & 1 & & 3 & & & \\
\hline $\begin{array}{l}\text { Gość } \\
\text { Niedzielny }\end{array}$ & 2 & & 1 & & & & & & \\
\hline Nowa Biblioteka & & & & & & & & & 1 \\
\hline $\begin{array}{l}\text { Praktyka i Teoria } \\
\text { Informacji Naukowej } \\
\text { i Technicznej }\end{array}$ & 1 & & & & & 1 & & & \\
\hline $\begin{array}{l}\text { Przegląd } \\
\text { Biblioteczny }\end{array}$ & & & & & & & 1 & 2 & \\
\hline $\begin{array}{l}\text { Studia i Materiały } \\
\text { z Dziejów Śląska }\end{array}$ & & & & 1 & & & & & \\
\hline $\begin{array}{l}\text { Śląskie Studia Histo- } \\
\text { ryczno-Teologiczne }\end{array}$ & & & & & 2 & 1 & & 1 & 2 \\
\hline $\begin{array}{l}\text { Śląski Kwartalnik } \\
\text { Historyczny Sobótka }\end{array}$ & & & & 1 & & & & & \\
\hline Razem & 8 & 5 & 6 & 5 & 6 & 9 & 4 & 11 & 13 \\
\hline
\end{tabular}

${ }^{24}$ Zob. Opisy bibliograficzne wszystkich opublikowanych prac bibliotekarzy BT znajdują się w Bibliografii Dorobku Pracowników Uniwersytetu Śląskiego [Dokument elektroniczny]. Tryb dostępu: http://www.bg.us.edu.pl/index.php?option=com_content\&view=article\&id=1172 [data dostępu: 8.11.2011]. 
Najwięcej artykułów opublikowano w recenzowanym czasopiśmie Federacji Bibliotek Kościelnych FIDES, zatytułowanym FIDES: Biuletyn Bibliotek Kościelnych. Od siedmiu lat pracownicy BT systematycznie współpracują z biuletynem umieszczając w nim swoje teksty, a od 2009 roku jeden z nich znalazł się także w składzie redakcji i pełni funkcję sekretarza. W tym samym roku dwie osoby z biblioteki dołączyły do redakcji kolejnego czasopisma zatytułowanego Bibliotheca Nostra: Śląsk Kwartalnik Naukowy, które podobnie jak FIDES także jest periodykiem recenzowanym, a powstaje przy współudziale trzech instytucji: Biblioteki UŚ, Biblioteki Głównej Akademii Wychowania Fizycznego w Katowicach oraz Instytutu Bibliotekoznawstwa i Informacji Naukowej UŚ. Poza tym publikacje pojawiały się w dwóch seriach wydawniczych: „Studiach i Materiałach Wydziału Teologicznego Uniwersytetu Śląskiego” oraz „Studiach Bibliologicznych” wydawanych w ramach „Prac Naukowych Uniwersytetu Śląskiego w Katowicach”. Jeden z tomów serii publikowanej przez WT poświęcono w dużej części działalności BT zamieszczając artykuły wszystkich pracowników, w których omówiono zagadnienia związane z komputeryzacją instytucji, gromadzeniem księgozbioru oraz współpracą z Federacją FIDES ${ }^{25}$. Zarys monograficzny dotyczący działalności, roli i znaczenia BT jako elementu systemu informacyjno-bibliotecznego Biblioteki UŚ ukazał się także w wydawnictwie zwartym zatytułowanym „Biblioteka otwarta: wczoraj i jutro Biblioteki Uniwersytetu Sląskiego"26.

Zakres tematyczny opublikowanych prac jest szeroki, jednak w przeważającej części dotyczyły one realizacji poszczególnych procesów bibliotecznych, zawartości gromadzonego księgozbioru oraz wydarzeń, które miały miejsce na terenie BT lub imprez, w których bibliotekarze uczestniczyli. Pierwsze prace poświęcone uruchomieniu oraz udostępnieniu zasobów książnicy dla całej społeczności akademickiej Śląska ukazały się zaraz po otwarciu WT. Informacje takie zamieszczono w lokalnej gazecie uniwersyteckiej ${ }^{27}$, regionalnej prasie katolickiej ${ }^{28}$ oraz ogólnopolskim czasopiśmie elektronicznym przeznaczonym dla bibliotekarzy ${ }^{29}$. W kolejnych latach wraz z rozwojem placówki bibliotekarze zaczęli poruszać tematy odnoszące się bezpośrednio do wykonywanych prac oraz niektórych elementów procesu bibliotecznego. Szeroko omawiano problematykę gromadzenia zbiorów

${ }^{25}$ Biblioteki kościelne i klasztorne w Polsce: historia i współczesność, red. H. Olszar, B. Warząchowska, Katowice 2009, s. 93-154.

${ }^{26}$ B. Warząchowska, Zbiory Biblioteki Teologicznej w stużbie spoteczności akademickiej, w: Biblioteka otwarta: wczoraj i jutro Biblioteki Uniwersytetu Ślaskiego, red. M. Kycler, D. Pawelec, Katowice 2008, s. 327-340; B. Warzachowska, Działalność Biblioteki Teologicznej Uniwersytetu Śląskiego, „Śląskie Studia Historyczno-Teologiczne”, 2 (2006) s. 516-528.

${ }^{27}$ B. Warząchowska, Wyrosta z dobrego drzewa, „Gazeta Uniwersytecka UŚ”, 6 (2002) s. 26-27.

${ }^{28}$ B. Warząchowska, Czytaj na Wita Stwosza, „Gość Niedzielny” Dodatek Katowicki, 5 (2002) s. 23.

${ }^{29}$ B. Warząchowska, Stara biblioteka nowego wydzialu Uniwersytetu Śląskiego [dokument elektroniczny], „Biuletyn EBIB” 6 (2002). Tryb dostępu: http://ebib.oss.wroc.pl/2002/35/warzachowska.php [data dostępu: 8.11.2011]. 
z podziałem na zakup książek ${ }^{30}$, wymianę ${ }^{31}$ i dary ${ }^{32}$, oraz oddzielnie przedstawiono gromadzenie czasopism ${ }^{33}$. Bibliotekarze zdobyli na tym polu duże doświadczenie, ponieważ BT jako jedyna w całym systemie biblioteczno-informacyjnym UŚ ma możliwość prowadzenia odrębnej polityki gromadzenia dokumentów, dlatego jako jedyna dokonuje zakupów oraz prowadzi systematyczną wymianę zbiorów. Kolejnym problemem poruszanym w prasie, a związanym bezpośrednio z gromadzeniem i zarządzaniem księgozbiorem była selekcja i preselekcja, ponieważ dary stanowią największe źródło wpływu dokumentów i wymagają wnikliwej analizy przed podjęciem decyzji o ich wprowadzeniu ${ }^{34}$.

Znacząca część publikacji poświęcona była księgozbiorowi bibliotecznemu, co miało na celu przede wszystkim poinformowanie otoczenia o jego zawartości, ale jednocześnie służyło jego promowaniu ${ }^{35}$. Podobne funkcje spełniały artykuły poświęcone wystawom przygotowywanym przez pracowników biblioteki ${ }^{36}$. Kolejnym chętnie poruszanym tematem była współpraca BT podejmowana zarówno

${ }^{30}$ E. Lubojańska, Gromadzenie i uzupetnianie zbiorów w Bibliotece Teologicznej ze środków Kurii Metropolitalnej w Katowicach, FIDES, 1-2 (2010) s. 30-490; E. Lubojańska, Zakup literatury naukowej ze środków własnych i projektów badawczych (grantów) Wydziału Teologicznego Uniwersytetu Śląskiego w Katowicach, w: Biblioteki kościelne, s. 119-131; A. Muc, Zakup ksiązek w Bibliotece Teologicznej Uniwersytetu Ślaskiego, ABMK, 88 (2007) s. 133-144.

${ }^{31}$ E. Olszowy, Wymiana krajowa w Bibliotece Teologicznej Uniwersytetu Ślaskiego, ABMK 82 (2004) s. 177-186; E. Olszowy, Wymiana zagraniczna Bibliotece Teologicznej, w: Biblioteki kościelne, s. 132-145; E. Olszowy, Źródta informacji wydawniczej o piśmiennictwie teologicznym wykorzystywane przy prowadzeniu wymiany w Bibliotece Teologicznej, FIDES, 1-2 (2006) s. 135-145.

32 B. Warząchowska, Dary w Bibliotece Teologicznej Uniwersytetu Śląskiego, ABMK, 89 (2008) s. 397-406.

${ }_{33}$ J. Październiok, Gromadzenie czasopism w zbiorach Biblioteki Teologicznej, w: Biblioteki kościelne, s. 111-118.

${ }^{34}$ A. Jurek, Wspótpraca bibliotek kościelnych w przekazywaniu dubletów i druków zbędnych. Wykorzystanie nowoczesnych form zarzadzania zbiorami, FIDES, 1-2 (2010) s. 140-149; B. Warząchowska, Selekcja i preselekcja zbiorów w bibliotece naukowej na przyktadzie Biblioteki Teologicznej Uniwersytetu Ślaskiego w Katowicach, FIDES, 1-2 (2006) s. 104-114.

${ }^{35}$ B. Kołodziej, Kolekcja arcybiskupa Szczepana Wesolego - dar dla zbioru kościelnego Biblioteki Teologicznej, w: Biblioteki kościelne, s. 143-147; E. Olszowy, Niemieckojęzyczne czasopisma wydane na Śląsku do 1945 r. w zbiorach Biblioteki Teologicznej Uniwersytetu Sląskiego w Katowicach, „Śląskie Studia Historyczno-Teologiczne”, 1 (2006) s. 178-190; B. Warząchowska, , Corpus Christianorum” w zbiorach Biblioteki Teologicznej, w: Biblioteki kościelne, s. 148-154; B. Warząchowska, Dzieje książek skonfiskowanych w roku 1960 w Bibliotece Śląskiego Seminarium Duchownego w Krakowie, „Studia i Materiały z Dziejów Śląska”, 26 (2005) s. 222-229; B. Warząchowska, Kolekcja książek księdza Stanisława Janasika w Bibliotece Teologicznej Uniwersytetu Śląskiego w Katowicach, „Śląskie Studia Historyczno-Teologiczna”, 2 (2010) s. 354-367; B. Warząchowska, Powrót aresztowanych książek, „Gość Niedzielny” Dodatek Spec. 2004, s. 3; B. Warząchowska, Rok Świętego Pawła $w$ dysertacjach Wydziału Teologicznego Uniwersytetu Ślaskiego w Katowicach, FIDES, 1-2 (2009) s. 130-143; B. Warząchowska, Skarby w ksiażnicach: księgozbiory klasztorne $i$ kościelne w Bibliotece Teologicznej, „Gazeta Uniwersytecka UŚ”, 6 (2007) s. 26.

${ }^{36}$ B. Warzachowska, Ekspozycje zbiorów Biblioteki Teologicznej, FIDES, 1-2 (2007) s. 80-89; B. Warząchowska, Promocja zbiorów Biblioteki Teologicznej w Katowicach, FIDES, 1-2 (2010) s. 150-168; B. Warzachowska, Wystawa naukowej książki zagranicznej w Bibliotece Teologicznej, „Gazeta Uniwersytecka UŚ”, 4 (2003) s. 9-10; B. Warzachowska, Wystawy, kiermasze, targi: książki do nas czy my do książek, FIDES, 1-2 (2004) s. 86-92. 
w najbliższym otoczeniu ${ }^{37}$, jak i na skalę ogólnokrajową ${ }^{38}$. Obok współpracy instytucjonalnej, opisywano także indywidualne kontakty i aktywność bibliotekarzy w środowisku ${ }^{39}$.

Największą część publikacji stanowią sprawozdania z wydarzeń, jakie miały miejsce na terenie BT lub WT oraz w najbliższym otoczeniu. Przybliżony charakter mają prace powstałe przy okazji udziału bibliotekarzy w konferencjach lub szkoleniach odbywanych w celu podniesienia kwalifikacji i wiedzy zawodowej. Pomimo, że nie zawsze w bezpośredni sposób odnosiły się one do biblioteki, to jednak pośrednio służyły jej promowaniu, gdyż przy każdym tekście zamieszczano afiliację autora. W podobny sposób należy traktować recenzje książkowe oraz artykuły stanowiące wynik indywidualnych badań i zainteresowań pracowników.

Ważny dla prestiżu biblioteki był także udział bibliotekarzy w opracowywaniu haseł do publikacji przygotowywanych przez pracowników WT - Stownika biograficznego duchowieństwa (archi)diecezji katowickiej 1922-2008 ${ }^{40}$ oraz Encyklopedii wiedzy o Kościele katolickim na Ślasku ${ }^{41}$. Poza tym systematycznie uczestniczą oni w pracach bibliograficznych współtworząc Bibliografię Dorobku Pracowników Uniwersytetu Śląskiego (rejestrują wszystkie publikacje pracowników WT) oraz Elektroniczna Bibliografię Nauk Teologicznych ${ }^{42}$.

Zarówno publikowanie artykułów bezpośrednio odnoszących się do działalności BT, jak i własna aktywność piśmiennicza bibliotekarzy sprzyjają promowaniu instytucji oraz mają wpływ na tworzenie jej pozytywnego wizerunku w otoczeniu, co często znajduje potwierdzenie w rozmowach z czytelnikami i przedstawicielami środowiska bibliotekarskiego.

${ }^{37}$ B. Warząchowska, Formy wspótpracy Biblioteki Teologicznej w środowisku lokalnym, FIDES, 1-2 (2005) s. 24-36; B. Warząchowska, Praktyki zawodowe studentów Instytutu Bibliotekoznawstwa i Informacji Naukowej Uniwersytetu Ślaskiego w Katowicach w Bibliotece Teologicznej Uniwersytetu Ślaskiego, w: Biblioteki i ośrodki informacji - zbiory, pracownicy, użytkownicy, red. M. Jarczykowa, Katowice 2010, s. 236-248.

${ }^{38}$ G. Łącka, Wspótpraca Biblioteki Teologicznej z Federacją Bibliotek Kościelnych FIDES, w: Biblioteki kościelne, s. 93-102.

${ }^{39}$ M. Kalczyńska, S. Błaszczyk, B. Warząchowska, E. Wojak-Kwoka, B. Kwoka, Absolwenci bibliotekoznawstwa o sobie, „Gazeta Uniwersytecka UŚ”, wyd. spec. 2005, s. 11; B. Warząchowska, Bibliotekarze strażnicy słowa Maryi, „Gość Niedzielny”, 24 (2002) s. 23; B. Warząchowska, Duszpasterstwo Bibliotekarzy. FIDES 1-2 (2003) s. 200-205; B. Warząchowska, Pielgrzymowanie - nowa forma integracji środowiska bibliotekarskiego [Dokument elektroniczny], „Biuletyn EBIB”, 7 (2003). Tryb dostępu: http://ebib.oss.wroc.pl/2003/47/pielgrzymka.php. [Data dostępu: 8.11.2011].

${ }^{40}$ Stownik biograficzny duchowieństwa (archi)diecezji katowickiej 1922-2008, red. J. Myszor, Katowice 2009, ss. 482.

${ }^{41}$ Encyklopedia wiedzy o Kościele katolickim na Ślasku [Dokument elektroniczny]. Tryb dostępu: $\mathrm{http}: / /$ www.encyklo.pl/index.php5?title=Strona_g\%C5\%82\%C3\%B3wnam [data dostępu: 8.11.2011].

${ }^{42}$ Elektroniczna Bibliografia Nauk Teologicznych [dokument elektroniczny]. Tryb dostępu: http://www.fides.org.pl/cgi-bin/ebnt/makwww.exe [data dostępu: 8.11.2011]. 


\section{Budowanie wizerunku biblioteki poprzez kontakty $\mathrm{z}$ otoczeniem}

Wynikiem dobrze prowadzonych działań z zakresu PR, a co za tym idzie dobrej komunikacji z otoczeniem, jest nawiązywanie współpracy oraz budowanie trwałych więzi.

Biblioteka podejmuje różnorodne formy kontaktów zarówno w środowisku lokalnym ${ }^{43}$, jak i na skalę ogólnopolską. Jednym z przykładów współpracy lokalnej jest aktywny udział w Sekcji Bibliotek Szkół Wyższych Stowarzyszenia Bibliotekarzy Polskich przy Zarządzie Okręgu w Katowicach, którą powołano w 2004 roku w celu zintegrowania środowiska bibliotekarskiego aglomeracji śląskiej ${ }^{44}$. Sekcja organizuje konferencje naukowe, warsztaty, wyjazdy studyjne do różnych bibliotek w kraju i za granica, dyskusje na aktualne tematy z zakresu bibliotekarstwa i informacji naukowej. Pracownicy śląskich bibliotek spotykają się systematycznie w ramach Forum Bibliotekarzy, otwartego dla całego środowiska bez względu na rodzaj książnicy, w jakiej są zatrudnieni. Dotychczas zorganizowano 26 tego rodzaju spotkań, podczas których zainteresowani mogli poszerzyć swoją wiedzę m.in. z zakresu zarządzania instytucjami non-profit, PR, prawa autorskiego, komunikacji, globalizacji informacji itp. BT w sposób czynny uczestniczy w zebraniach Rady Programowej Sekcji organizując niektóre ze spotkań i konferencji naukowych. W 2007 roku w siedzibie biblioteki odbyło się IX Forum Sekcji Bibliotek Szkół Wyższych. Poruszana wówczas problematyka księgozbiorów klasztornych i kościelnych przyciągnęła bibliotekarzy uczelni wyższych całego środowiska śląskiego, a nawet zdecydowanie wykroczyła poza to środowisko. W spotkaniu uczestniczyli, oprócz bibliotekarzy praktyków różnych typów bibliotek, bibliotekoznawcy z Instytutu Bibliotekoznawstwa i Informacji Naukowej UŚ (dalej: IBIN UŚ), a także osoby z instytucji pokrewnych bibliotekom - archiwów, muzeów i instytutów naukowo-badawczych oraz pracownicy naukowi z macierzystego $\mathrm{WT}^{45}$. Natomiast w 2009 roku w ramach XVI Forum Sekcji zorganizowanego we współpracy z Federacją Bibliotek Kościelnych FIDES odbyła się konferencja - Finanse bibliotek naukowych a ochrona dóbr kultury. Celem konferencji było ukazanie znaczenia finansów, sposobów ich pozyskiwania i odpowiedniego wydatkowania $\mathrm{w}$ różnego typu bibliotekach stanowiących jedno z podstawowych dóbr kultury. Problematyka obrad oscylowała głównie wokół możliwości zabezpieczenia środków na nowoczesne budownictwo biblioteczne, konserwacją, ochronę i digitalizację zbiorów ${ }^{46}$. Ponownie wśród zainteresowanych problematyką gości znaleźli się obok przedstawicieli bibliotek z całego kraju, także pracownicy naukowi oraz studenci UŚ. Podczas obydwu konferencji bibliotekarze z BT występowali z referatami dotyczącymi działalności biblioteki, co pozwoliło poka-

${ }^{43}$ B. Warząchowska, Formy wspótpracy Biblioteki Teologicznej w środowisku lokalnym, FIDES, 1-2 (2005) s. 25.

${ }^{44}$ B. Urban, O działalności Sekcji Bibliotek Szkół Wyższych przy Zarządzie Okręgu SBP w Katowicach, „Bibliotekarz”, 5 (2006) s. 21.

${ }^{45}$ G. Łącka, Problematyka księgozbiorów klasztornych i kościelnych: sprawozdanie z IX Forum Sekcji Bibliotek Szkót Wyższych SBP w Katowicach, FIDES, 1-2 (2006) s. 146-150.

${ }^{46}$ A. Muc, Sprawozdanie z konferencji „Finanse bibliotek naukowych a ochrona dóbr kultury”, „Bibliotheca Nostra”, 17 (2009) s. 39-41. 
zać ją jako instytucję aktywną naukowo i dodatnio wpłynęło na budowę jej wizerunku. Ponadto organizacja tego rodzaju spotkań stanowi doskonałą okazję zaprezentowania książnicy oraz jej osiągnięć szerszej publiczności.

Nieco inny charakter kontaktów ma współpraca bibliotekarzy BT w ramach istniejącego od 1999 roku Duszpasterstwa Bibliotekarzy ${ }^{47}$. W Archidiecezji Katowickiej duszpasterstwo zostało powołane jako jedno z pierwszych w Polsce, a inicjatorami jego powstania byli członkowie ówczesnego Zarządu Okręgu Stowarzyszenia Bibliotekarzy Polskich. Skupia ono pracowników ze wszystkich typów bibliotek, dla których ważne są wartości chrześcijańskie, dlatego jednym z głównych jego celów stała się oprócz wymiany doświadczeń i współpracy zawodowej, także integracja tego mocno rozproszonego środowiska. W ramach duszpasterstwa organizowana jest coroczna ogólnopolska pielgrzymka na Jasną Górę, pielgrzymowanie do kościołów pod wezwaniem św. Wawrzyńca - patrona bibliotekarzy oraz liczne spotkania okolicznościowe np. z okazji Dnia Bibliotekarza, wieczory opłatkowo-kolędowe, prelekcje, wykłady teologiczne itp. U źródeł powołania duszpasterstwa znajdowała się idea teologiczna i uznanie faktu, że zaangażowanie religijne może i powinno służyć doskonaleniu pracy bibliotekarskiej ${ }^{48}$.

Obok współpracy lokalnej BT prowadzi także szeroko zakrojoną współpracę na skalę ogólnokrajową, czego przykładem jest czynny udział bibliotekarzy w pracach oraz obecność w zarządzie Federacji Bibliotek Kościelnych FIDES. Federacja została erygowana przez Konferencję Episkopatu Polski w 1995 roku i obecnie zrzesza ponad 80 bibliotek członkowskich, w tym większość bibliotek wydziałów teologicznych i wyższych seminariów duchownych w Polsce, a także książnice diecezjalne i zakonne. Podstawowym celem organizacji jest integracja oraz usprawnianie działalności polskich bibliotek kościelnych poprzez wdrażanie postępu technicznego, a w szczególności koordynację prac związanych z komputeryzacją. Biblioteki zrzeszone w Federacji mają ułatwiony dostęp do szkoleń oraz poradnictwa w zakresie różnych aspektów działalności bibliotecznej, a zwłaszcza dotyczących sprzętu i wdrażania nowych programów i usług komputerowych np. systemu MAK, formatu MARC 21. Biuro ds. Rozwoju i Komputeryzacji Federacji FIDES zainicjowało opracowanie multiwyszukiwarki FIDKAR, dzięki której możliwe jest prowadzenie wyszukiwań w wielu komputerowych bazach bibliograficznych jednocześnie. FIDKAR umożliwia przeglądanie w tym samym czasie kilkudziesięciu katalogów bibliotecznych, bibliografii zawartości czasopism, bibliografii tematycznych oraz katalogów dysertacji. Ułatwia to nie tylko prowadzenie prac bibliograficznych, ale także znacząco usprawnia proces katalogowania dokumentów poprzez kopiowanie ich opisów bezpośrednio do katalogów komputerowych poszczególnych bibliotek. Wymiana doświadczeń zawodowych

${ }^{47}$ B. Warząchowska, Duszpasterstwo bibliotekarzy, FIDES, 1-2 (2003) s. 20-205; B. Warząchowska, Pielgrzymowanie - nowa forma integracji środowiska bibliotekarskiego [Dokument elektroniczny], „Biuletyn EBIB”, 7 (2003). Tryb dostępu: http://ebib.oss.wroc.pl/2003/47/pielgrzymka. php [data dostępu: 8.11.2011].

${ }^{48}$ Zob. Duszpasterstwo Bibliotekarzy Archidiecezji Katowickiej [Dokument elektroniczny]. Tryb dostępu: http://www.bs.katowice.pl/inne/duszpasterstwo/diecezja_katowice.po.php [data dostępu: 8.11.2011]. 
oraz informacji pomiędzy bibliotekami członkowskimi Federacji jest prowadzona także za pośrednictwem wspominanego już czasopisma FIDES: Biuletyn Bibliotek Kościelnych. BT od początku swego istnienia aktywnie udziela się w pracach organizacji oraz dokumentuje swoją działalność na łamach biuletynu. W 2007 roku zorganizowała XIII Walne Zgromadzenie Federacji. Na spotkanie do Katowic przybyli oprócz bibliotekarzy z całej Polski zrzeszonych w Federacji, także przedstawiciele śląskich uczelni i bibliotek. Miejscem obrad była aula WT, natomiast w BT odbyło się spotkanie integracyjne bibliotekarzy połączone ze szkoleniami przywarsztatowymi, podczas których pracownicy BT przedstawili swoje stanowiska pracy i zakresy czynności, zapoznając osoby zainteresowane z obiegiem dokumentów bibliotecznych, drogą książki od zakupu poprzez akcesję, opracowanie po udostępnianie. Oprócz organizacji jednostki, zaprezentowano także historię i księgozbiór biblioteki oraz stan komputeryzacji. Zgromadzeniu trwającemu trzy dni towarzyszyły wykłady wygłoszone przez pracowników IBIN UŚ, bibliotekarzy z Biblioteki Uniwersytetu Wrocławskiego oraz przedstawiciela $\mathrm{BT}^{49}$.

Kolejnym ważnym obszarem współpracy na skalę ogólnokrajową oraz zagraniczną, jest samodzielne prowadzenie wymiany publikacji. BT jako jedyna w systemie biblioteczno-informacyjnym UŚ posiada swobodę podejmowania decyzji zarówno w zakresie nawiązywania jak i prowadzenia wymiany. Ta forma działalności miała w pierwszej kolejności jedynie zasięg krajowy, kiedy to na terenie Polski zaczęto podejmować współpracę z różnymi bibliotekami (uniwersyteckimi, wydziałowymi, instytutów teologicznych i naukowych, seminaryjnymi), muzeami oraz redakcjami czasopism ${ }^{50}$. W miarę rozwijania i utrwalania kontaktów z instytucjami w kraju zaczęto rozszerzać współpracę także na ośrodki zagraniczne, głównie w Niemczech, Włoszech i Słowacji, takie jak np. Herder-Institut w Marburgu, Hannah-Arendt-Institut für Totalitarismusforschung w Dreźnie, Biblioteka Pontificia Università Urbaniana, Prešovská Univerzita w Prešove ${ }^{51}$. Obecnie biblioteka współpracuje z blisko osiemdziesięcioma instytucjami polskimi i kilkunastoma zagranicznymi. Dzięki wymianie BT na bieżąco wzbogaca swój księgozbiór o nowe pozycje, ma możliwość uzupełniania braków w kolekcjach, także o tytuły niedostępne na rynku księgarskim oraz promuje dorobek naukowy WT na forum krajowym i międzynarodowym. Dodatkową korzyścią wynikającą ze współpracy jest wymiana wzajemnych doświadczeń zawodowych oraz wiedzy w zakresie opracowania zbiorów, komputeryzacji czy informacji naukowej.

Prowadzenie systematycznej współpracy zarówno instytucjonalnej, jak i utrzymywanie kontaktów indywidualnych przez bibliotekarzy zapewnia stały kontakt z otoczeniem bliższym oraz dalszym biblioteki, sprawia że jest ona postrzegana jako instytucja otwarta i aktywna, co z kolei dodatnio wpływa na jej wizerunek.

${ }^{49}$ B. Warząchowska, Federacja Bibliotek Kościelnych FIDES (Katowice), „Śląskie Studia Historyczno-Teologiczne”, 42 (2007) s. 279; B. Warząchowska, Federacja Bibliotek Kościelnych FIDES w Katowicach, „Gazeta Uniwersytecka UŚ”, 3 (2007) s. 21.

${ }^{50}$ Olszowy, Wymiana krajowa, s. 177-186.

${ }^{51}$ Olszowy, Wymiana zagraniczna, s. 132 


\section{Dydaktyka biblioteczna jako jedna z form promocji osobistej}

W bibliotekach zawsze ogromne znaczenie i tradycję miał osobisty kontakt bibliotekarza z czytelnikiem. Bezpośrednie obcowanie pozwala lepiej poznać odbiorcę produktów bibliotecznych, a w szczególności poznać jego opinię na temat funkcjonowania instytucji. Ten rodzaj relacji stanowi podstawę wyróżnienia bardzo istotnego, choć może niekiedy niedocenianego instrumentu promocyjnego biblioteki, jakim jest promocja osobista, która w porównaniu $\mathrm{z}$ reklamą na pewno jest tańsza i bardziej skuteczna, chociaż ustępuje jej pod względem zasięgu. W swoich kontaktach z czytelnikiem bibliotekarz udziela mu porad, pomocy, informuje o usługach biblioteki, dążąc przy tym do nakłonienia go do skorzystania $\mathrm{z}$ danej oferty. Dlatego tak ważne jest, aby kadra biblioteczna oprócz kwalifikacji zawodowych posiadała także odpowiednie predyspozycje osobowościowe oraz umiejętność komunikowania się z użytkownikiem. Od życzliwości i uprzejmości pracowników, zwłaszcza zatrudnionych w działach udostępniania i informacji czy w czytelni, zależy społeczna opinia o bibliotece, a w szerokiej perspektywie sympatia środowiska ${ }^{52}$. Postawa bibliotekarzy jest istotnym elementem kształtowania wizerunku zewnętrznego instytucji. Ważność udziału pracowników w kształtowaniu wizerunku zapisana jest w Kodeksie etyki bibliotekarza i pracownika informacji, gdzie czytamy: „1. Są lojalnymi pracownikami. Dbają o dobre imię swojej instytucji, zmierzają do wykreowania i utrwalenia w społeczeństwie jej pozytywnego wizerunku. 2. Dążą do rozumienia i pogłębiania wiedzy o zadaniach i celach macierzystej instytucji oraz wspierania ich prowadzoną działalnością" (cz. druga, rozdz. VI, ptk 1,2) ${ }^{53}$. Personel oprócz tego, że jest kreatorem wizerunku biblioteki w świadomości użytkowników, opinii społecznej, władz uczelni i potencjalnych sponsorów, to stanowi także nieodzowny warunek pełnego wykorzystania potencjału, jaki stanowią zbiory i usługi świadczone przez bibliotekę.

Najpopularniejszą formą bibliotecznej promocji osobistej jest wprowadzanie nowych czytelników do biblioteki, określane jako przysposobienie biblioteczne. W BT obejmuje ono kształcenie w zakresie posługiwania się katalogiem kartkowym i elektronicznym, zapoznanie z możliwościami korzystania z księgozbioru na miejscu w czytelni oraz wypożyczania na zewnątrz za pośrednictwem wypożyczalni. Tego rodzaju działalność dydaktyczna ma na celu przede wszystkim praktyczną prezentację sposobów posługiwania się biblioteką i poruszania się po sieci bibliotecznej UŚ. Zajęciami z przysposobienia bibliotecznego objęci są wszyscy studenci pierwszego roku studiów stacjonarnych i niestacjonarnych. Każdego roku zostaje przeszkolonych 210-230 studentów w zakresie ogólnej wiedzy korzystania z BT i innych bibliotek UŚ. Zajęcia przeprowadza się w Czytelni i Wypożyczalni w pierwszych dniach października. Przedmiot składa się z godzinnego

${ }^{52}$ A. Andrejów-Kubów, M. Podgórska, ,, Praca na froncie” jako droga do tworzenia wizerunku bibliotek, w: Marketing i jakość ustug bibliotek akademickich, Wrocław 2002, s. 13-19.

${ }^{53}$ Cyt. za J. Sadowska, Na marginesie zarządzania - wizerunek biblioteki, „Bibliotekarz”, 9 (2010) s. 16. 
wykładu oraz jednej godziny ćwiczeń i kończy się obowiązkowym zaliczeniem ${ }^{54}$.

Obok zbiorowej formy pracy z czytelnikiem każdego dnia w czytelni prowadzona jest systematyczna pomoc $\mathrm{w}$ poszukiwaniu informacji na konkretny temat. Zazwyczaj ma ona formę instruktażu udzielanego przez pracownika we wszystkich interesujących użytkownika sprawach, związanych z biblioteką i świadczonymi przez nią usługami. Dodatkowo bibliotekarze pomagają zainteresowanym osobom w racjonalnym i skutecznym wykorzystaniu otrzymanych materiałów bibliotecznych, sporządzaniu bibliografii lub przygotowaniu prac dyplomowych. Osobisty kontakt z czytelnikiem ma często charakter spontaniczny i przypadkowy, może nastąpić w każdym punkcie biblioteki i dotyczyć różnych, często nietypowych problemów. Czasami bywa tak, że czytelnik zwraca się z trudnym pytaniem, na które nie można odpowiedzieć natychmiast, wówczas bibliotekarz wyznacza termin, w którym zostanie udzielona wyczerpująca odpowiedź lub kieruje czytelnika do osób lepiej zorientowanych w danej problematyce. Promocja osobista jest również istotna przy oferowaniu przez bibliotekę nowych usług lub wprowadzaniu nowych technologii, co miało miejsce w BT np. podczas testowania baz danych lub nowych elektronicznych źródeł informacji.

Inną formą dydaktyki sprzyjającą promowaniu instytucji jest prowadzenie praktyk zawodowych dla studentów IBIN UŚ. Praktyki są jedną z trudniejszych i bardziej czasochłonnych form dydaktyki bibliotecznej. Działalność taka jest możliwa dzięki obecności odpowiedniego zaplecza organizacyjnego, lokalowego oraz informatycznego, a także co równie istotne odpowiednio przygotowanej kadry dydaktycznej i dobrze układającej się współpracy z pracownikami instytutu. Od 2002 roku w Bibliotece organizowane są zarówno wakacyjne, jak i śródsemestralne praktyki zawodowe dla studentów I i II roku studiów stacjonarnych ${ }^{55}$. Bibliotekarze dzieląc się swoją wiedzą i doświadczeniem pomagają przyszłym adeptom zawodu poszerzać i pogłębiać wiadomości teoretycznych oraz w praktyczny sposób przygotowują ich do wykonywania przyszłej pracy ${ }^{56}$. Istotne jest również podejście kadry do obecności studentów w bibliotece, traktowanie ich nie jako intruzów, zakłócających zwykły porządek dnia, ale jako partnerów podlegających tym samym prawom i obowiązkom, jakim podlegają etatowi pracownicy ${ }^{57}$. Ponadto na terenie BT odbywają się ćwiczenia z komputeryzacji bibliotek, zintegrowanych systemów bibliotecznych oraz zajęcia z praktycznych sposobów i form gromadzenia i opracowania zbiorów w bibliotece ${ }^{58}$. Równolegle z praktykami stu-

${ }^{54}$ Warząchowska, Dziatalność Biblioteki Teologicznej, s. 443.

${ }^{55}$ Warząchowska, Praktyki zawodowe, s. 236-247.

${ }^{56}$ B. Ćwiertnia, Dzień dzisiejszy praktyk zawodowych studentów Bibliotekoznawstwa i Informacji Naukowej (na przykladzie IBIN UŚ w Katowicach), w: Ksztatcenie bibliotekarzy dla przyszłości. Materiały z Ogólnopolskiej Konferencji Stowarzyszenia Bibliotekarzy Polskich, Jachranka k. Warszawy, 22-24 październik 1995, Warszawa 1996, s. 220.

${ }^{57}$ A. Chachlikowska, Zadania dydaktyczne współczesnej biblioteki akademickiej i możliwości ich realizacji na przykladzie Biblioteki Uniwersyteckiej w Poznaniu, w: Funkcje naukowo-badawcze i dydaktyczne biblioteki akademickiej. Materiaty konferencji naukowej Kielce, 19-21 września 1996, red. H. Suchojad, Kielce 1996, s. 195.

${ }^{58}$ Warząchowska, Praktyki zawodowe, s. 236-248. 
denckimi prowadzone są praktyki zawodowe dla pracowników z innych śląskich bibliotek naukowych, których odbycie jest konieczne przed uzyskaniem awansu na starszego bibliotekarza oraz kustosza. Dydaktyka w tym wypadku polega na przekazaniu podstawowych wiadomości na temat funkcjonowania i struktury organizacyjnej instytucji oraz sposobów realizacji zadań na poszczególnych stanowiskach pracy, takich jak gromadzenie, opracowanie, udostępnianie oraz informowanie. Dotychczas przeprowadzono praktyki dla bibliotekarzy ze Śląskiego Uniwersytetu Medycznego, Politechniki Śląskiej oraz Państwowej Wyższej Szkoły w Raciborzu.

Kolejną formą promocji prowadzonej przez BT jest przyjmowanie wycieczek uczniów ze szkół podstawowych, gimnazjów i liceów oraz prezentowanie im księgozbioru i zapoznawanie ich ze specyfiką działalności biblioteki kościelnej uczelni wyższej. W ramach promocji osobistej prowadzonej przez BT mieści się także obecność pracowników w sesjach naukowych i konferencjach organizowanych przez macierzysty WT, IBIN UŚ oraz biblioteki naukowe regionu, czyli aktywny udział personelu bibliotecznego w życiu społeczności lokalnej. Zdobyta w ten sposób wiedza sprzyja edukacji permanentnej pracowników i pozwala na ciągłe podnoszenie kwalifikacji, dzięki czemu bibliotekarze są postrzegani przez otoczenie jako osoby kompetentne i fachowe.

\section{Podsumowanie}

BT pomimo bogatej tradycji - jest spadkobierczynią książnicy Wyższego Śląskiego Seminarium Duchownego, jednocześnie jest stosunkowo młodą instytucją publiczną, ponieważ dopiero dziesięć lat temu otworzono ją dla śląskiej społeczności akademickiej i lokalnej. W tym czasie bibliotekarze starali się podejmować wiele różnorodnych działań mających na celu poinformowanie otoczenia o istnieniu i działalności biblioteki, jej bogatym i interdyscyplinarnym księgozbiorze oraz wciąż rozszerzającej się ofercie usług. Realizacji tego zamierzenia sprzyjało zastosowanie, odpowiednio dobranych i przystosowanych do specyfiki kościelnej biblioteki naukowej, instrumentów promocyjnych oraz, co jest równie ważne zaangażowanie całego personelu. Efektem szeroko prowadzonej działalności promocyjnej jest systematycznie rosnąca liczba wypożyczeń oraz zarejestrowanych czytelników, zarówno spośród studentów, jak i pracowników naukowych, którzy wywodzą się nie tylko z Uniwersytetu Śląskiego, ale także z innych uczelni regionu i kraju. 
PROMOTIONAL ACTIVITIES OF CHURCH ACADEMIC LIBRARIES ILLUSTRATED WITH AN EXAMPLE OF THE THEOLOGICAL LIBRARY OF UNIVERSITY OF SILESIA IN KATOWICE

\begin{abstract}
Summary
Promotional activities undertaken by the Theological Library at University of Silesia are primarily aimed at informing people about the content of the accumulated books and the offer of services. This goal is achieved by using, appropriately selected and adapted to the needs of the church academic library, promotional tools such as the exhibition advertising, public relations and personal promotion. What proved particularly helpful in creating a positive image of the institution was systematic exhibition advertising, educational and publishing activities, as well as maintaining contact with people through establishing cooperation with various research institutions and associations.
\end{abstract}

Translated by Aneta Kiper 